\title{
The Impact of Digital-Based Materials on Undergraduates' Reading Habit
}

\author{
Shahnil Asmar Saaid and Zaliffah Abd Wahab
}

\begin{abstract}
The objective of this paper was to examine the impact of digital-based materials on student's reading habit. The questionnaire research was conducted on Universiti Teknologi MARA (UiTM) students and consisted of questions that dealt with various aspects of digital-based reading materials and its consequences on students' reading habit. The survey results indicated that of 103 respondents, the majority of the respondents $(69.2 \%)$ read digital-based materials for leisure rather than research $(18.1 \%)$ and study $(12.7 \%)$. In seeking the respondents' biggest impact of digital emergence, this study revealed that $62.2 \%$ agreed that their reading habits have changed and their interest in reading have developed due to the emergence of digital materials such as online newspapers, e-book and e-magazines. The majority used laptop to assess these digital-based materials and none of the respondents use E-Readers. Future studies should assess the usage of these digital reading devices among Malaysians especially the students as the trend of digital textbooks is gaining popularity among textbook publishers.
\end{abstract}

Index Terms-Digital-based materials, reading habits, undergraduates, digital reading.

\section{INTRODUCTION}

Reading is an important and most significant activity in a society. It is important for people to acquiring knowledge and information. Even though information may appear in many different media, the point is people still need to read. According to Shariza and Amelia [1], reading is regarded as a process, a mode of thinking, a kind of real life experience and involves many complex skills. Reading comes as a result of the interaction between the perception of graphic symbols that represent knowledge, and the reader's language skills and knowledge of the world. It is the meaningful interpretation of printed or written verbal symbols. Reading is said to help in individual's well-being and self development. Karim and Hassan [2] also stated that the thirst for reading and wider dissemination of books is a sign of progress in the world.

The studies in reading have come from various academic disciplines such as education, social sciences as well as information systems. Some studies also based on the demographic factors; ages, gender, culture and social status. As for example, Grzeschik, et al. [3] found that female is likely to read heavily than male. Another popular study is reading comprehension. Reading comprehension, therefore,

Manuscript received July 17, 2013; revised September 27, 2013. This work was financed by Universiti Teknologi Mara (UiTM).

The authors are with the Publishing Program, Faculty of Communication and Media Studies, UiTM, 40450 Shah Alam, Selangor, Malaysia (e-mail: asmarsaaid, zalif754, @ salam.uitm.edu.my). is a process of making sense out of text; it is a process of using one's existing knowledge (schemata) to interpret text in order to construe meaning [4]. Dickson et al. [5] suggest reading comprehension is a multifaceted process where several factors such as IQ, instructional approach, task dimensions, motivation and time on task could affect comprehension. They take reading comprehension to be a cognitive activity that is accomplished by a mental information-processing system that is made up of a number of distinct processing subsystems. The nature and functioning of this mental information-processing system is expected to change as a reader becomes more practiced and skilled and acquires new knowledge. According to the research done by Atan Long in 1982, the habit of reading does not appear to be a prominent feature in the lives of most Malaysians [3]. It found that Malaysian had poor reading habits and did not like reading. The statistics from the National Statistic Department, 2005 shows that reading is not even the favorite pastime of Malaysian as most prefer to watch television and video. The statistics also show that more than half of the 60,441 odd Malaysians surveyed read less than seven pages a day. And those 10 years and above read about two books a year. Shahriza and Amelia [1] suggested that Malaysian student read for academic purposes only, and not for general knowledge. They, however, proposed that the trend may have shifted to a digital reading habit as the finding on types of reading material are highly ranked by students by 70\%. Daily Expressed on 2010 reported that even though majority of Malaysia are equipped with literacy skills, the reading habits are still at an unsatisfactory level [6]. Many students perceived that reading is a waste of time and they only read for purpose of passing examinations. This was supported by the research done by Pandian [7] which came out with two major concerns. According to him, 20\% of Malaysian read regularly and the rest are "reluctant readers". He suggested that if the phenomenon is left unattended, the Malaysia's future would eventually be directed by reluctant readers' who are a way behind from knowledge, intelligence and maturity.

However, the coming of digital media may explain the difference in reading habits among Malaysians [1]. People are now using the web and wireless solution to satisfy their information needs. It is found that $46 \%$ of the respondents (public university students) get the reading materials from the Internet and followed by the library (20\%), friends (23\%) and the bookstores (16\%) [1].The finding also shows that the pattern of youth readings changed from printed-based material to digital based material. The growth of the Internet is the core to this change as Internet is the backbone of digitizing printed publication, either for promotional or 
educational purposes. Since then, people, especially the youth is very much dependent on the internet to find reading materials because this medium is more accessible and more cost effective and less time consuming. Moreover, younger people tend to be heavy Internet and cell phone users [8]. Basically, digital materials in the context of this research include book, magazine, journal and other articles that can be read digitally. Digital based material is viewed as an electronic version of a paperback. It may be accessible via the Internet and read using the e-book reader such as a Web browser. eBook, for example, is the form of digital publication in which it can be defined as a digital version of a book that can be read on Web or even with other electronic reading device such as Rocket e-book or Pocket PC. eBooks can now be read on a large number of devices including PCs, laptop, netbooks, tablet computers, mobile phones, PDA's and portable games console [9,6]. Apple introduce an iBook's application for it users to download and read books. This application is available for iPad and iPhone users. iBooks includes the iBookstore, where users are able to download the latest best-selling books or their favorite classics - day or night. It is an interactive application that allows users to browse the library on a beautiful bookshelf, tap a book to open it, flip through pages with a swipe or a tap, and bookmark or add notes to the favorite passages. With the growing amount of digital information available and the increasing amount of time that people spend reading electronic media, the digital environment has begun to affect people's reading habit. Therefore, the general objective of this study is to analyze the impact of digital-based materials on students' reading habits. The specific objective is to assess if there is a significance difference between reading habit of digital and printed materials.

\section{PRoblem StATEMENT}

With the growing amount of digital information available and the increasing amount of time that people spent on reading electronic media, the digital environment has begun to affect people's reading behavior. According to a recent study, 93\% of those aged 12-29 use online system, while those aged 29 years and above nearly $74 \%$ of them use the Internet [10]. These statistics show that people are becoming digital at an alarming rate [11]. A number of scholars also argue that the arrival of digital media, together with the fragmentary nature of hypertext, is threatening sustained reading $[8,11,3,12]$. Birkerts [13] suggests that the younger generation who growing up in the digital environment lacks the ability to read deeply and to sustain a prolonged engagement in reading. Moreover, the development of digital libraries is participating a general societal trend toward shallower, more fragmented, and less concentrated reading [12]. On the other hand, some argues that digital media have served as a catalyst leading to new styles of printed books with graphics in new forms and formats, nonsequential organization, and multiple layers of meaning. Youth are spending increasing amounts of time in conversations with others in this nonlinear, hyperlinked environment which has significantly influenced the way in which youth read and interact with each other [14]. These statements show that the current technology has greatly influenced the reading habit among the students. Hence, the purpose of this paper is to study the habit of reading among undergraduates so that it will advance a useful solution for the delivery and management of digital reading materials in higher education. The general objective of this study is to analyze the impact of digital-based materials on undergraduates" reading habit. The specific objectives are to determine the characteristics of digital reading among undergraduates and to assess their reading patterns, both on printed and digital based materials.

\section{Methodology}

A quantitative research method was used in this study where a sample of questionnaire was distributed to students of Publishing Program from semester one to five of Faculty of Communication and Media Studies, Shah Alam, Selangor. Population is a group or class of subjects, variable, concepts or phenomenon [15]. Sample on the other hand is a subset of the population that represents the entire population. By using simple random sampling, each individual is chosen entirely by chance and each member of the population has an equal chance of being in the sample. In this study, the technique applied is based on the table of Krejcie and Morgan [16]. This table is to determining needed sizes of a randomly chosen sample from a given finite population of $\mathrm{N}$ cases. Such that the sample proportion $\mathrm{P}$ will be within $+/-0.5$ of the population $\mathrm{P}$ with the 95 percent level of confidence. According to Kerjie and Morgan, if the population of Publishing Program student of Communication and Media Studies Faculty is 139, hence the sample is 103. Only students who have used and read digital-based materials were selected as respondents. The questions formulated were based on the research questions and were designed as close-ended which requires respondents to choose from a list on answers given in the questionnaires. In line with the objectives of the study, all respondents are first asked about their awareness on the arising of digital publication, followed by their reading patterns and interests on reading digital and printed publications. Common characteristics and situational factors were also asked. This, in turn, helped to build a conceptual framework for reading habit of digital materials among students. All variables were measured using five-point Likert scale from 1 (strongly disagree) to 5 (strongly agree). Higher score indicated higher values. All data were tested using SPSS for Windows.

\section{RESUlTS AND DiscUSSION}

\section{A. Demographic Data}

Out of 103 respondents, the majorities (60.2\%) were female and followed by male $(39.8 \%)$. This is perhaps due to imbalance gender distribution of the university population, particularly in Publishing Program. A high majority of the respondents were between $21-25$ years old $(84.5 \%), 15$ to 20 years old $(13.6 \%)$ and 25 to 30 years old $(1.9 \%)$. Meanwhile, the majorities were in semester five $(38.8 \%)$, followed by semester four $(22.3 \%)$, semester three $(18.4 \%)$, semester one $(14.6 \%)$ and semester two $(5.8 \%) .100 \%$ of them did aware 
of the existing of digital books.

\section{B. Reading Patterns of Printed-Based Materials}

For the purpose of both academic and leisure, a majority of students read printed publications such as newspapers, books or magazines almost every day $(46.6 \%)$, followed by $3-5$ times a week $(32.0 \%)$, less than 3-5 times a week (16.5\%), and whenever necessary or when the materials are available $(4.9 \%)$. Four types of reading materials such as book, magazine, journal and others were presented to the respondents. They were allowed to choose more than one type of reading materials. The majority of students read magazines $(50 \%)$, and books $(30.8 \%)$ other materials such as newspapers, novels, etc. (13.5\%) and the least number was for journal $(5.8 \%)$. It is believed that journal reading was done merely for academic purposes.

TABLE I: TYPES OF READING MATERIALS

\begin{tabular}{llll}
\hline \hline Reading Materials & $\mathrm{N}$ & Percent & $\begin{array}{l}\text { Reading } \\
\text { Materials }\end{array}$ \\
\hline Book & 32 & $30.8 \%$ & $46.6 \%$ \\
Magazine & 51 & $50.0 \%$ & $75.7 \%$ \\
Journal & 6 & $5.8 \%$ & $8.7 \%$ \\
Other & 14 & $13.5 \%$ & $20.4 \%$ \\
TOTAL & 103 & $100.0 \%$ & $151.5 \%$ \\
\hline \hline
\end{tabular}

Even though the majority of students read almost every day, the number of those who were not reading regularly (21.4\%) can be considered quite high thinking that students supposed to read almost every day. On average, students took less than one hour to read in a day (46\%), followed by 1-2 hours a day $(42 \%)$ and very few students read more than 3 hours a day (12\%). This data supported Pandian's [20] finding which stated $80 \%$ of Malaysian university students are reluctant readers for both English and Malay materials.

TABLE II: TIME SPENT FOR READING IN A DAY

\begin{tabular}{lllll}
\hline \hline Frequency & Percent & $\begin{array}{l}\text { Valid } \\
\text { Percent }\end{array}$ & $\begin{array}{l}\text { Cumulative } \\
\text { Percent }\end{array}$ & Frequency \\
\hline <1 hour & 46 & 44.7 & 44.7 & 44.7 \\
1 -2 hour & 42 & 40.8 & 40.8 & 85.4 \\
$>3$ hour & 15 & 14.6 & 14.6 & 100.0 \\
Total & 103 & 100.0 & 100.0 & \\
\hline \hline
\end{tabular}

Several sources were identified to be used by the respondents to get their reading materials. These were bookstores, libraries, friends and others. Bookstore was found to be the most frequent used sources to get the printed reading materials (46\%), followed by borrowing from friends $(25 \%)$, libraries $(14.2 \%)$ and others $(13.6 \%)$. When were asked to state their main purpose of reading, the students read more for leisure or entertainment $(58.2 \%)$ than research $(23.3 \%)$ and study purposes $(18.4 \%)$. The results suggested that students read was mainly to fulfill their enjoyment and gratification rather than reading academically.

\begin{tabular}{ccc}
\multicolumn{2}{c}{ TABLE III: MAIN PURPOSE OF READING FOR PRINTED MATERIALS } \\
\hline \hline Purpose of reading & $\mathrm{N}$ & Percent \\
\hline Research & 24 & $23.3 \%$ \\
Leisure & 60 & $58.2 \%$ \\
Study & 19 & $18.4 \%$ \\
TOTAL & 103 & $100.0 \%$ \\
\hline \hline
\end{tabular}

\section{Reading Patterns of Digital-Based Materials}

This study revealed that $39.8 \%$ of the respondents read digital text every day (much lower than the printed materials which account for $46.6 \%$ ) while the other (31.1\%) read 3-5 times a week and $(29.1 \%)$ less than 5 times a week. The time spent on reading digital text per day showed that a majority of the respondents read less than one hour $(56.3 \%)$, followed by 1-2 hours $(32 \%)$ and less than 3 hours $(11.7 \%)$. This data suggests no significance different between hours spent per day on reading digital and printed texts. However, the percentage of reading digital text for less than one hour is considerably high than the printed texts perhaps due to the inability to read digital screen in a long period of time. In this case, many of them preferred to print out the digital versions. This supports the study by McKnight [17] who observed that people do not like to read from computer screens. They preferred to read from printed documents or even print those out from dot matrix printers. Most of them also agreed that reading through printed versions were more comfortable and easy to comprehend the content.

TABLE IV: READING PATTERNS OF DigitAL MATERIALS

\begin{tabular}{lllll}
\hline \hline Purpose of reading & $\begin{array}{l}\text { Freque } \\
\text { ncy }\end{array}$ & Percent & $\begin{array}{l}\text { Valid } \\
\text { Percent }\end{array}$ & $\begin{array}{l}\text { Cumulative } \\
\text { Percent }\end{array}$ \\
\hline 1-2times a week & 41 & 39.8 & 39.8 & 39.8 \\
3-5times a week & 32 & 31.1 & 31.1 & 70.9 \\
>5times a week & 11 & 10.7 & 10.7 & 81.6 \\
1-2times a month & 10 & 9.7 & 9.7 & 91.3 \\
>2times a month & 9 & 8.7 & 8.7 & 100.0 \\
TOTAL & 103 & 100.0 & 100.0 & \\
\hline \hline
\end{tabular}

TABLE V: DEVICES USED FOR READING DIGITAL MATERIALS

\begin{tabular}{lll}
\hline \hline $\begin{array}{l}\text { Devices use for reading digital } \\
\text { material }\end{array}$ & $\mathrm{N}$ & Percent \\
\hline Laptop & 16 & $15.5 \%$ \\
Tablet & 29 & $28.0 \%$ \\
iPad & 19 & $18.4 \%$ \\
Smartphone & 39 & $37.8 \%$ \\
Others (Kindle, etc) & 0 & $0 \%$ \\
TOTAL & 103 & $100.0 \%$ \\
\hline \hline
\end{tabular}

TABLE VI: MAIN PURPOSE OF READING FOR DIGITAL-BASED MATERIALS

\begin{tabular}{lll}
\hline \hline $\begin{array}{l}\text { Purpose of } \\
\text { reading }\end{array}$ & $\mathrm{N}$ & Percent \\
\hline Research & 28 & $28.1 \%$ \\
Leisure & 43 & $42.2 \%$ \\
Study & 23 & $22.7 \%$ \\
Other & 9 & $7.0 \%$ \\
(entertainment) & & \\
TOTAL & 103 & $100.0 \%$ \\
\hline \hline
\end{tabular}

The results also showed that most of the students read magazine digitally $(32 \%)$ followed by journal $(27 \%)$, books $(20.3 \%)$ and others $(19.6 \%)$. Increasing number in reading digital journal as compared to print journal (5.8\%) was probably due to the accessibility factor where journals are easily available in a digital form, particularly through online. Most of these materials were accessed from different sources such as students' own laptop or computers (36\%), followed by the computer labs (29\%), libraries $(18.8 \%)$ and other devices $(14.8 \%)$. The most popular internet device used to read digital text was smart phone $(37.8 \%)$ as compared to 
tablet $(28 \%)$, iPad (18\%) and Laptop (15.5\%). None of the student used e-Reader devices such as Amazon's Kindle Portable, Nintendo DS-lite and Apple iPod Touch.

No significance different was found in the purpose of reading between printed and digital texts where the majority of the respondents read for leisure $(42.2 \%)$ rather than research $(28.1 \%)$ and study $(22.7 \%)$.

\section{Consequences of Digital Emergence on Reading Habits}

In seeking the respondents' biggest impact or consequences of digital emergence, this study reveals that $62.2 \%$ of the respondents agreed that their reading habits had changed and their interest in reading had developed due to the emergence of digital publications such online newspapers, magazines, books and journals. Out of all respondents, $54.4 \%$ agreed that digital materials helped them to better understand the subjects, $34 \%$ were undecided and the other $11.7 \%$ of them disagreed. As compared to printed materials, $36.9 \%$ agreed that digital publications are easier to read, however, $34 \%$ disagreed with the claim. The other $28.2 \%$ was neither agreed nor disagreed. This suggests that paper is unlikely to disappear in the digital age and it is still the people's preference for a medium of reading (especially in-depth reading) [3], [18]-[20]. It is also suggested that in the digital age, printing for reading remains one of the major driving forces for the increasing consumption of paper. The research also shows that the respondents $(42.8 \%)$ could read the digital materials for a long period of time while $28.2 \%$ undecided and $29.1 \%$ did not agreed that digital materials could be read for a longer period. This is consistent with the finding when they were asked whether they preferred the digital text to be printed, a majority of the respondents $(57.3 \%)$ agreed, the other $24.3 \%$ undecided and $18.4 \%$ disagreed. Digital-based materials seem to be more a more practical medium to read for most of the respondents when $51.5 \%$ agreed with the statement. Their reading interests have also developed due to the emergence of digital publication. However, the majority of them (76.9\%) will normally print out the reading materials for prolonged reading. This is consistent with the finding by Ramirez [21] who found that nearly 80 percent of students prefer to read a digital peace of text in printed form rather than digital. In this study, $36.9 \%$ of the respondents agreed that reading digital publication will tire their eyes. Others $(63.1 \%)$ felt that they were losing focus when read digitally. Another significant finding from the study indicated that the respondents" reading comprehension was not disrupted by digital reading. $69.9 \%$ of the respondents agreed that their reading comprehension remains the same when reading digitally or printed whilst $30.1 \%$ disagreed with the statement. The result explains that their level of comprehension did not influence by the reading methods. This, however, is contradicted to the research finding by Dillon et al. [22] where they found that reading comprehension is slower from screen reading than from paper.

\section{CONCLUSION AND RECOMMENDATION}

Results showed that digital materials were preferred by students than the print materials. This is in accordance with the findings by Gianci [11] who reported that the evolution of the digital society is most evident among the students. Students entering higher education now or those who were born between 1982 and the early 2000s, are members known as the 'Net Generation'. These students are "digital native" which means that they have grown very comfortable with technology and use it in many situations [23]. According to Tapscott [23], these are the generations choose freedom to make a choice in life and they want to fit a lot of things into their own hands. Innovation is also part of their lives. The finding also revealed that the amount of time spent on reading, however, is considered low as most of the students read less than an hour per day. Students spent more times to read printed material as compared to digital where it showed that they felt uncomfortable reading digital texts for a longer period. The reason being is due to the loss of concentration and tiring their eyes. For both printed and digital-based materials, magazines remain the most popular reading material among the respondents. They chose to read for pleasure but a significant number of respondents also chose to read because of their study-related activities such as doing research for the assignments. Here, the percentage for digital reading was considerably higher than the printed materials. However, the finding also showed that the majority of students read for leisure $(69.5 \%)$ rather than reading for academic matters $(30.4 \%)$. These statistics are quite alarming as the use of digital materials is seen more biased when it comes to academic purposes. In essence, we do not want to see the internet as purely a source of entertainment for the students rather than the source to increase their knowledge. In line with the results of this study, it suggested the possibility for students to use Internet merely for two major reasons - to assist them in completing their assignments and to pass their examinations [24]. This supported the statement made by Shariza and Amelia [1] that the students read for academic purposes only, not for general knowledge. Among others, the present study of digital publishing may explain the differences in reading habit among Malaysian. People are increasingly used the web and wireless solution to satisfy their information needs. However, if digital environment lacks the ability to sustain a prolonged engagement in reading [22], in-depth study should be done to overcome the problem so that the use of the digital-based materials can be beneficial to students.

The finding of the study also revealed that the majority of students used laptop to read digital-based materials thus suggested that electronic publication devices such as smartphone, iPad or tablet are still not popular as their digital reading devices. E-reader devices like Amazon's Kindle Portable, Nintendo DS-lite and Apple iPod Touch has not been used by any of the respondents. Further study may assess the usage and effectiveness of these digital reading devices among Malaysians especially among students as the trend of digital textbooks is gaining popularity among textbook publishers. Area of study may also seek to determine on how to increase sustained attention of reading in digital environment. Reading digitally tends to distract readers attentions with the heavy feature in the interface. Therefore, method should be implemented to avoid such 
problem to enhance the readers' comprehension and concentration. In addition, knowing more about the reading patterns of digital-based materials helps publishers design more effective systems and services in the future. Generally, from the study it can be concluded that digital-based materials has an impact on the students. It impacted particularly on aspects such as their reading materials, reading interest and reading time.

\section{REFERENCES}

[1] M. Shariza and A. Amelia. (2006). Male Teenagers Need for Extensive Reading. [Online]. Available: http://www.iium.edu.my/ilc/?download=16-e08.pdf

[2] N. S. Karim and A. Hasan, "Reading habits and attitude in the digital age: Analysis of gender and academic program differences in Malaysia," Electronic Library, vol. 3, pp. 285-298, 2007.

[3] K. Grzeschik, Y. Kruppa, D. Marti, and P. Donner. (2011). Reading in 2110 - reading behavior and reading devices: a case study. Electronic Library. [Online]. 29(3). pp. 288-302. Available: http://www.emeraldinsight.com/

[4] J. D. McNeil, Reading Comprehension: New Directions for Classroom Practice, 3rd Edition, Harper Collins Publisher: New York, 1992.

[5] S. V. Dickson, D. C. Simmons, and E. J. Kameenui, "Text organization and its relation to reading comprehension: A synthesis of research," Technical Report, ERIC Document: ED386864, 1995.

[6] J. Z. Abidin. (2011). A Survey of Online Reading Habits of Rural Secondary School Students in Malaysia. [Online]. Available: http://www.macrothink.org/

[7] A. Pandian, "Literacy in Postcolonial Malaysia," Journal of Adolescent \& Adult Literacy, vol. 40, no. 5, pp. 402-404, 1997.

[8] B. W. Cull. (2011). Reading revolutions: Online digital text and implication for reading in academic. [Online]. Available: http://firstmonday.org/

[9] N. Abdullah and F. Gibb, "Students attitudes towards eBooks in a Scottish Higher Education Institute," Library Review, vol. 57, no. 8, pp. $593-605,2008$

[10] A. Lenhard, "Teens and mobile phones over the past five years: Pew Internet looks back," Washington, D.C: Pew Internet and American Life Project, 2009.

[11] A. M. Gianci, "Redefining the Textbook: A user-centered approach to the creation, management and delivery of digital course content in higher education," MA Thesis, Graduate School of The Ohio State University, 2011.

[12] D. M. Levy, "I read the news today, oh boy: Reading and attention in digital libraries," in Proceedings of the 2nd ACM International Conference on Digital Libraries, Philadelphia, PA, 1997, pp. 202-211.

[13] S. Bikerts, The Gutenberg Elegies; The Fate of Reading in an Electronic Age, Faber and Faber, Boston, MA, 1994.

[14] R. L. Cross. (2011). Digital books and the salvation of academic publishing. Bottom Line: Managing Library Finances. [Online]. 24(3). pp. 162-166. Available: http://www.emeraldinsight.com/

[15] R. D. Wimmer and J. R. Dominick, "Mass media research," Belmont, Ca.: Thompson Wadsworth, 2006.

[16] R. V. Krejcie and D. W. Morgan, "Determining sample size for research activities," Educational and Psychological Measurement, vol. 30, pp. 607-610, 1970.
[17] C. Knight, "Electronic JournalsL What do Users Think of Them?" in Proceedings of the International Symposium on Research, Development and Practice in Digital Libraries, 1997.

[18] Z. Liu. (2005). Reading behavior in the digital environment: Changes in reading behavior over the past ten years. Journal of Documentation. [Online]. 61(6). pp. 700-712. Available: http://www.emeraldinsight.com/

[19] D. McAllister, N. McAllister, and S. Vivian. (2001). The impact of digital books upon print publishing. [Online]. Available: http://www.bosonbooks.com/boson/

[20] A. J. Sellen and R. H. R. Harper, The Myth of the Paperless Office, MA: The MIT Press, Cambridge, 2002.

[21] E. Ramirez. (2003). The Impact of the Internet on the Reading Practices of a University Community: the case of UNAM. Proceedings of the 69th IFLA General Conference and Council. [Online]. Available: http:/www.ifla.org/IV/ifla69/papers.

[22] A. Dillon, J. Richardson, and C. McKnight, "The effect of display size and paragraph splitting on reading lengthy text from screen," Behaviour and Information Technology, vol. 9, no. 3, pp. 215-227, 1990.

[23] D. Tapscott, "Grown up digital: How the net generation is changing your world," New York: McGraw-Hill, 2009

[24] A. Pandian, "A study on readership behaviour among multi-ethnic, multi-lingual Malaysian students," presented at the 7th International Literacy and Education Research Network (LERN) Conference on Learning, RMIT University, Melbourne, 5-9 July 2000.

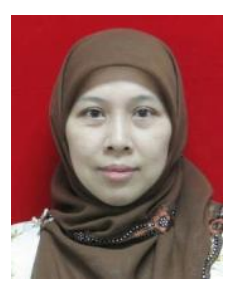

Shahnil Asmar Saaid is a Malaysian, born on November 30, 1968. She received her BA Mass Communication (Publishing) at Universiti Teknologi MARA (UiTM) in 1992, MA in Publishing \& Book Production at University of Plymouth, UK in 1998 and MPhil in Typography \& Graphic Communication at University of Reading, UK, in 2008. She has been teaching at the Faculty of Communication and Media Studies, UiTM for more than 15 years. She has presented paper in the area of book publishing, typography, and media studies. She is also a member of Technical Expert in Education and Publishing, appointed by the Ministry of Science, Technology and Innovation, Malaysia.

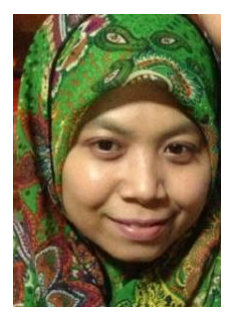

Zaliffah Abd Wahab is a lecturer at the Faculty of Communication and Media Studies UiTM (Publishing Programme) and currently pursuing a $\mathrm{PhD}$ in the School of Media and Communication Studies (MENTION), Universiti Kebangsaan Malaysia. She holds a Bachelor of Arts Degree in Mass Communication from UiTM in 1996 specialising in Publishing studies. Prior to joining UiTM as a lecturer at UiTM in 2000, she served BERNAMA (Malaysian News Agency) for nearly 4 years as an Executive officer under the Corporate News Services from 1996-2000. She also attained her Masters Degree in Science Information Management (UiTM) from UiTM in 2000. She has since been lecturing and supervising students at Degree and Masters level at UiTM. Her areas of research interest include electronic publishing, visual communication, contemporary publishing and typography. 